\title{
Proposed Design of a Network Supply Chain for the Cocoa Agro Chain of Viota Municipality, Cundinamarca
}

\section{Propuesta de Diseño de una Red Supply Chain para la Agrocadena de Cacao, Municipio de Viotá, Cundinamarca}

\author{
dx.doi.org/10.17981/ijmsor.01.01.05
}

Research Article - Reception Date: December 9, 2015 - Acceptance Date: December 27, 2015

\author{
Alexander Sepúlveda Perico, \\ Servicio Educativo Nacional de Aprendizaje SENA \\ asepulvedap@misena.edu.co, Bogotá, Colombia \\ Roberto Martínez Castro \\ Servicio Educativo Nacional de Aprendizaje SENA \\ rmartinezc@misena.edu.co, Bogotá, Colombia \\ Samir Medina Roncancio \\ Servicio Educativo Nacional de Aprendizaje SENA \\ samirmedina@misena.edu.co, Bogotá, Colombia \\ Fernando Salazar Arrieta \\ Corporación Universidad de la Costa - CUC \\ fsalazar4@cuc.edu.co, Barranquilla, Colombia
}

To reference this paper:

A. Sepúlveda Perico, R. Martínez Castro, S. Medina Roncancio and F. Salazar Arrieta "Proposed Design of a Network Supply Chain for the Cocoa Agro Chain of Viota Municipality, Cundinamarca", IJMSOR, vol. 1, no. 1, pp. 35-42, 2016. DOI: dx.doi.org/10.17981/ijmsor.01.01.05

\begin{abstract}
The paper addresses the proposed design of a network Supply Chain to the agro chain of cocoa in the town of Viota Cundinamarca, from the application of concepts of principles and theories related to network management and logistics, emphasizing the strategic processes in collaborative environments from a practical implementation in a real context of farmers to the industrial customer that meets the needs of the region expressed through the "Asociación de Cacaoteros del Bajo Tequendama Viota" -ASCABATE, (Cocoa Farmers Association of Low Tequendama Viota - ASCABATE) and recorded by research conducted through an interview of 10 farmers in the region. The analysis yields a set of data that demonstrate the need for integration between cocoa farmers in the municipality with suppliers of agricultural inputs, services and also with clients such as Casa Luker and Nacional de Chocolates; the definition of a network Supply Chain that integrates these actors for development of farmers and their families, the functionality of a union is evident from the identification of the Leading Company as an integrating part of the network poses with the purpose of linking farmers union members in the association ASCABATE which shows how to play this role, including suppliers, customers and others who directly or indirectly participate in the collaborative process to create value as a benefit to Viota region.
\end{abstract}

Keywords-- Supply Chain Management, Value Networks, Logistics, Strategic Processes, Agricultural Chains.

\begin{abstract}
Resumen-- El documento aborda la propuesta de diseño de una red Supply Chain para la agrocadena de cacao en el municipio de Viotá Cundinamarca, desde la aplicación de conceptos de principios y teorías relacionadas con la Gestión de redes de valor y Logística, enfatizando en los procesos estratégicos en entornos colaborativos desde una implementación practica en un contexto real de productores agrícolas hasta el cliente industrial que se ajusta a las necesidades de la región expresada a través de la Asociación de Cacaoteros del Bajo Tequendama de Viotá -ASCABATE, y registrada mediante investigación realizada, a través de una entrevista, a 10 agricultores de la región. El análisis arroja una serie de datos que evidencian la necesidad de integración entre los cultivadores de cacao del municipio con los proveedores de agro insumos, de servicios y así mismo con clientes como Casa Luker y la Nacional de Chocolates; se plantea la definición de una red Supply Chain que permite integrar a estos actores en pro del desarrollo de los cultivadores y sus familias, se comprende la funcionalidad de una unión a partir de la identificación de la Empresa Líder como parte integradora de la red Supply Chain, con el propósito de vincular a los agricultores agremiados en la asociación ASCABATE la cual se prospecta como la que desempeñaría este papel, entre proveedores, clientes y otros actores que; de manera directa o indirecta, participen en el proceso colaborativo para generar valor como un beneficio a la región de Viotá.
\end{abstract}

Palabras claves-- Redes de Valor, Logística, Cacao, Procesos Estratégicos, Supply Chain Management, Agro-cadenas. 


\section{INTRODUCTION}

In the municipality of Viota, cocoa farming is developed mainly by a small group of farmers, in individual property farms; many of these farmers struggle to make a living against difficulties like the aging of trees, loss of soil fertility, non-attended plagues and that destroy their crops. Presently, more than six million cocoa farmers in the world support their families through the planting, care and harvest of cocoa grains, the raw material of processed chocolate, used to elaborate chocolate, caramels and other products [1].

The challenges faced by these small cocoa farmers, due to the conditions of their farms, are multiplied, among other causes, by the nonexistence of a value network, which limits access to information, to knowledge about better practices, to the big buyers and market information. This is the reason that motivates the master research team in Management of Value and Logistics Networks, III cohort, to become integrated to the Project Frame of Universidad Piloto de Colombia named Productive and Associative Model, Cocoa Supply Chain in the Provinces of Sumapaz and Tequendama (Cundinamarca), Viota Epicenter [2], with the project "design proposal of a network supply chain for the COCOA Agro chain in the municipality of Viota, Cundinamarca", with the purpose of promoting the Cocoa Farmers Association of Low Tequendama, with 57 members, 7 of which are permanently dedicated to farming cocoa, meaning only $12.28 \%$. It is necessary then, to promote the Supply Chain Network, with the intent of improving the cultivation of cocoa in the region, the increase of production and propose the development of agreements with the big cocoa commercializing companies, as manifested by Luis Eduardo Moreno Malagón [3], representative of the Cocoa Farmers Association of Low Tequendama, which gathers together the producers of this fruit, from the municipalities of Anapoima, Apulo, Tocaima and Viota.

In this regard, and with the purpose of strengthening the transference of technologies in the agricultural cultivation of cocoa in Viota and other municipalities of Cundinamarca, as well as raising the technical level of the officials of Umata, The Office of the Agricultural and Rural Development Secretary of Cundinamarca, in association with the Company Casa Luker, a course was programmed about the agroforestry production system of cocoa, plantain and forestry. It was taught at Luker Farm in Palestina (Caldas) from November 29 to December $3^{\text {rd }}, 2010$ [4].

In Colombia, the agricultural and agroforestry sectors represent one of the most important sectors of the economy, because their economic relevance places it in the fifth place of the activities that contribute more to the Gross Internal Product (GIP), with a $12 \%$ participation, according to an evaluation made by Agro chains [5]. The Cocoa Chain encompasses the production of the bean, its processing and production of chocolate and sweets. According to [6], $75 \%$ of cocoa is absorbed by the processing companies through stockpilers or authorized agents fort purchasing the beans, and the rest is destined to small processors or for export in marginal volumes.

According to [5], the Productive Chain of Cocoa - Chocolate contributes $2.4 \%$ of agricultural jobs; in the industry of cocoa transformation and manufacture of chocolates, the contribution is $1.5 \%$ to the total of food industry, and $0.3 \%$ to the total of the manufacturing industry. The industry takes care of the processing and elaboration of cocoa by-products. According to [7] in the chain mainly intervene four types of agents: farmers (approximately 25.000 producers), stockpilers, exporters and the processing industry.

Since it is a crop for small farmers, cocoa has not benefited from the research and technical support which helped increase the productivity and profitability of basic food crops. Fort the cocoa industry to become truly sustainable, these farmers must change into a priority for all, in order to be able to make their small farms a professional affair, increase their profits, diversify their crops, and support their families [1].

This article summarizes the "Design proposal of a Supply Chain Network for the Cocoa Agro chain in the municipality of Viota, Cundinamarca", through the same name Project, as a sequence of interconnected commercial activities that add value in a progressive manner to the bean crop, to the post-harvest and commercialization, taking advantage of the government industrial policy about increasing the possibilities of the sector in terms of export, and strengthen the productivity of the cocoa link, as expressed by [8].

In the first part of the work, the background of establishing a Supply Chain Networks is analyzed and the approach to the problem, goals and theoretical frame are performed. In a second section, a characterization and diagnosis are made about the cocoa crop in the region of Viota, Cundinamarca. In a third section, it is assessed the design proposal of a Supply Chain Network for the cocoa agro chain in the municipality of Viota and its social, environmental and economic impact. Finally, the conclusions and recommendations are set to be considered in future researches on the subject.

\section{Background-Problematic Condition:}

In the municipality of Viota, Cundinamarca, Colombia, as per the 2010 - 2014 Development Plan, the intention is to strengthen cocoa production for the economic development of the region, as well 
as strengthening and developing the Productive Transformation Program-PTP-on the basis of 12 strategic importance sectors, which are: auto parts, graphic communication industry, cosmetics and cleaning products, textiles, clothes manufacturing, design and fashion, chocolate and sweets factories, and their raw materials. In the meantime, agriculture is like a locomotive that performs, among others, two functions: recuperate the agro as the economic leader sector of the country and become the essential element of social development, even allowing the recovery of the country considering the conflict we have had to face, as manifested by [9].

According to the Viota Mayor's Office [10] the municipality has approximately 20.567 rural hectares, of which 14.560 hectares correspond to small producers with small farmsteads of less than 5 hectares and the remaining 6.107 hectares, are major exploitations. $67.8 \%$ of the rural sector is exclusively dedicated to agricultural work. The municipality is considered the first coffee producer of the department, with $28 \%$ participation of the registered production in Cundinamarca. The coffee growing zone is spread in 30 rural districts, located between the 1000 and 2000 meters above sea level, and cover an extension of approximately 4.818 hectares, held mostly by small producers. Plantain is the second agricultural sector, covering more than 700 hectares. Mango is another crop grown in that zone, with an extension of 450 hectares. Cocoa is a new crop in the zone, but with great force within the production alternatives, for it is a permanent crop, the agro ecological conditions of the municipality are excellent for its development; it is estimated that the municipality has approximately 272 cultivated cocoa hectares.

For this, the advances of the agricultural sector are set into seven strategies: i) Increase the competitiveness of the agricultural and livestock production; ii) promote the chaining and value aggregation; iii) widen and diversify the internal and external markets; iv) promote risk management structures; v) improve the capacity to generate profits; vi) promote equity in the rural regional development and; vii) adapt the institutionalism for rural development and competitiveness. According to [9], in the first quarter of 2011 there were 4.31 million of rural jobs generated, of which 2.9 million came from agricultural and livestock activities. The percentage of working people dedicated to agricultural activities, fishing, cattle, hunting and silviculture (OAPGCS) went from $64.6 \%$ in the first quarter of 2010 to $67.3 \%$ during the same period of 2011.

In that order of ideas, the Universidad Piloto with the Macro project "Design, implementation, management and projection of research and development (I\&D) of the Industrial and Company Complex for Central and West Cundinamarca, Viota epicenter": bolstering the Region City", brings an opportune response, supported on the different disciplines at undergraduate, post graduate and master levels; directing the research projects to the concretion of proposals that positively impact this region.

The research team visited the municipality of Viota on June 7, 2013, with the purpose of interviewing the main actors in the Cocoa Agro chain, and thus structure the proposed design of a Supply Chain Network, considering the description made by The Global Supply Chain Forum: "The members of a Supply Chain are all the companies or organizations with which the target company directly or indirectly interact from the origin to the destination point. But to ensure that a very complex network becomes more manageable, we must differentiate between primary and secondary or support participants", and the network structure proposed by [11].

In the exercise with the farmers, they manifested how their crops develop every day and its commercialization process. Below we describe the results of the activity:

According to statements of [12] president of the Cocoa Association of Low Tequendama - ASCABATE, the same is composed by 57 members, but not all are permanently farming cocoa, and most do not have an appropriate technique for harvesting. He argues that they lack government support and there are no established programs to technically improve cocoa farming, and the result is a low production without the opportunity to make agreements with the big companies, like Procacao, with whom there were meetings, and their minimum supply requirements are 5 tons of the product. Since the farmers do not have the production capacity to supply this amount, the negotiations were dropped. On the other hand, with Casa Luker, another big buyer, they tried to commercialize the product, but one of the barriers is the required high quality standards, which is Premier type Cocoa; all else is considered bulk cocoa.

When analyzing this information, we identify a need to classify the variety of crops to establish a greater quality product, and some farmers agree that one of the best varieties is the Araucana, however with technical support from SENA a hybrid variety was identified as appropriate, according to the technical specifications of the company Casa Luker.

\section{Methodological Design}

The study is part of the Macro Project named " $D e$ sign, implementation, management and projection of research and development $(I \& D)$ of the Industrial and Company Complex for Central and West Cundinamarca, Viota epicenter": bolstering the Region City". 
Viota was founded on March 27, 1777; it has a population of 13.430 inhabitants, it is located south west of Cundinamarca department, with the following coordinates: 4.433 of Latitude, longitude, -74.517 $4^{\circ} 25^{\prime} 59^{\prime \prime} \mathrm{N}$, and $74^{\circ} 31^{\prime} 1^{\prime \prime} \mathrm{W}$, in the Province of Tequendama, and with an extension of $208 \mathrm{~km} 2$, at a distance of $82.7 \mathrm{~km}$ from the city of Bogotá D.C., as per data of Viota, Peace Territory [13].

The technical contribution to the Macro Project stars in the month of February, 2014, with the analysis of the information and database supplied by the research teams of the Universidad Piloto de Colombia. Once verified the information, the coherence graphic and research protocol are executed, where it is defined what is a non-experimental research, and the appropriated methodology for the research which is direct observation and registry, and analysis of the primary and secondary sources information; the appropriated technique is the correlational quantitative and qualitative through structured observation. The target study population is the cocoa sector belonging to the agro chain. The sample frame allows for the selection of elements, ensuring the possibility of all been selected [14]. Under this premise are identified the leader farmers conforming the link of the cocoa agro chain in the region of Viota, Cundinamarca.

The information registry instrument is designed, with the purpose of performing a structured interview to the cocoa growers of Viota municipality, Cundinamarca, and support in this way the obtained information in the following aspects: identification of the actors (producers) - table 1, the cocoa market - table 2, support services (enrollment, land preparation, sowing, harvest and post- harvest) table 3, about suppliers (Agro input and services)table 4 , about commercialization -table 5, negotiation and prices -table 6 , as shown below:

\section{Actors and bushels dedicated to Cocoa}

Table 1 Bushels dedicated to Cocoa farming

\begin{tabular}{|l|l|c|c|}
\hline \multicolumn{1}{|c|}{ NAME } & \multicolumn{1}{|c|}{ FARM } & HECTARES & $\begin{array}{c}\text { HECTARES } \\
\text { DEDICATED } \\
\text { TO COCOA } \\
\text { FARMING }\end{array}$ \\
\hline $\begin{array}{l}\text { José Leonidas } \\
\text { Hernández }\end{array}$ & El lobo & 3 & 1,5 \\
\hline $\begin{array}{l}\text { Campo } \\
\text { Ernesto Patiño }\end{array}$ & El Cerrito & 1 & 1 \\
\hline Rubiela García & El Pervenir & 4 & 4 \\
\hline $\begin{array}{l}\text { Roberto } \\
\text { Pedraza }\end{array}$ & La Esmeralda & 1 & 0,5 \\
\hline $\begin{array}{l}\text { Pastor } \\
\text { Castiblanco }\end{array}$ & Ubaté & 7 & 7 \\
\hline Policarpo & & 3 & 3 \\
\hline Luis Guzmán & & 1 & 1 \\
\hline TOTAL & & 20 & 18 \\
\hline
\end{tabular}

\section{COCOA FARMING}

- HECTARES DEDICATED TO COCOA FARMING

- OTHERS (Soursop, plantain, mango, tangerine, orange and coffee)

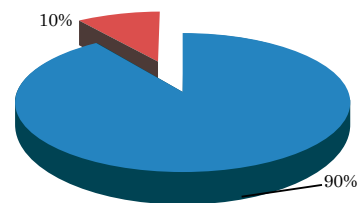

Source: Elaborated by the Research Team

Analysis: there is an average of 2.83 hectares dedicated to fruit crops like mango, cocoa, and citrus, among others. $90 \%$ is dedicated to cocoa, and the remaining $10 \%$ to other crops.

\section{Commercialization}

Table 2 Commercialization Place of Cocoa

\begin{tabular}{|l|c|}
\hline \multicolumn{1}{|c|}{ Description } & $\begin{array}{c}\text { Number of } \\
\text { Farmers }\end{array}$ \\
\hline Merchants from Viota and Girardot & 4 \\
\hline Cocoa Federation and Cooperative & 3 \\
\hline
\end{tabular}

WHERE IS THE PRODUCT SOLD?

- Merchants of Viota and Girardot

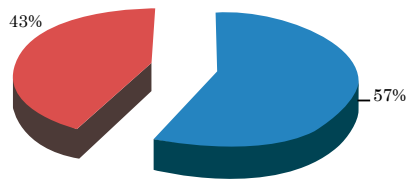

Source: Elaborated by the Research Team

Analysis: $57 \%$ of the target farmers for the analysis are registered as commercializing their product in the municipalities of Viota and Girardot; while the remaining $43 \%$ prefers the Cocoa Federation and Cooperative.

\section{Production}

Table 3 Production Capacity

\begin{tabular}{|c|c|}
\hline Description & Number of Farmers \\
\hline Up to $156 \mathrm{~kg} /$ Hectare & 4 \\
\hline Up to $157 \mathrm{~kg} /$ Hectare & 3 \\
\hline
\end{tabular}

WHAT ARE THE PRODUCTION VOLUMES?

- Up to $156 \mathrm{~kg} / \mathrm{Hectare} \quad \mathrm{Up}$ to $157 \mathrm{Kg} /$ Hectare

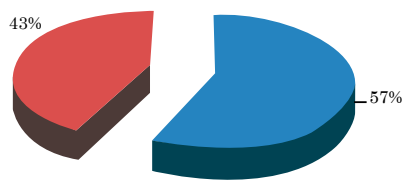

Source: Elaborated by the Research Team 
Análisis: $57 \%$ of the target farmers for the analysis are registered as having a production capacity of up to 156 kilograms per crop hectare of production, while the remaining $43 \%$ have a production rate superior to 157 cocoa kilograms per hectare.

\section{Services and Support}

Table 4 Packing

\begin{tabular}{|c|c|}
\hline Description & $\begin{array}{c}\text { Number of } \\
\text { Farmers }\end{array}$ \\
\hline Fique Sacks & 7 \\
\hline Others & 0 \\
\hline
\end{tabular}

WHAT IS THE PACKING USED FOR THE PRODUCT?

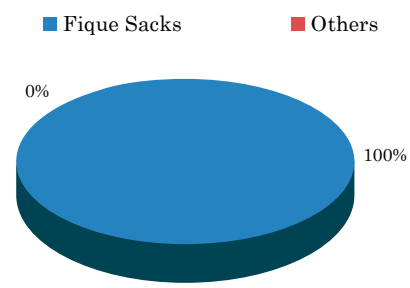

Source: Elaborated by the Research Team

Analysis: It was noted that $100 \%$ of the target farmers of this analysis use fique sacks for packing and commercializing cocoa.

\section{Commercialization}

Table 5 Measurement units for Commercialization

\begin{tabular}{|c|c|}
\hline Description & $\begin{array}{c}\text { Number of } \\
\text { Farmers }\end{array}$ \\
\hline Kilogram & 3 \\
\hline Sack & 4 \\
\hline
\end{tabular}

WHAT IS THE COMMERCIALIZATION MEASUREMENT?

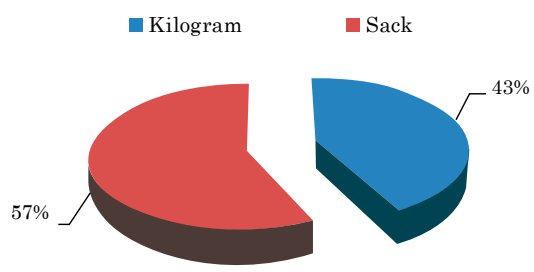

Source: Elaborated by the Research Team

Analysis: $57 \%$ of the target farmers for this analysis commercialize cocoa in equivalent parcels to 25 kilograms, while the remaining $43 \%$ packs them by kilograms, meaning, retail items; demonstrating that there are no standard units, which translates into less profits.
Cocoa Price

Table 6 Value of Cocoa

\begin{tabular}{|c|c|}
\hline $\begin{array}{c}\text { Description } \\
\text { (presentation) }\end{array}$ & Sale price \\
\hline Sack & $\$ 77.250$ \\
\hline Kilo & $\$ 3.200$ \\
\hline
\end{tabular}

WHAT IS THE SALE PRICE OF THE PRODUCT ACCORDING TO MEASUREMENT UNIT?

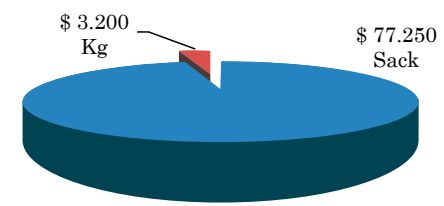

Source: Elaborated by the Research Team

Analysis: According to the collected information, the value paid for a $25 \mathrm{~kg}$ parcel is $\$ 77.250$ pesos; which proves thta the average sale value per kg., is $\$ 3.090$ pesos, which when sold in a different type of package, meaning, per kg., it is sold at an average of $\$ 3.500$ pesos, proving that there is a difference of $\$ 410$ pesos per $\mathrm{kg}$, however, in the interview with the farmers they mention that the price per cocoa $\mathrm{kg}$ may reach a price per $\mathrm{kg}$ of $\$ 4.800$ pesos when there are the proper conditions for the market.

\section{III.Discussion}

It is urgent in the región of Viota to define an organizational strategy to give producers a boost and integrate them with the logistic, production and input processes, which translates into benefits and sustainability for the cocoa crop in the region, since these municipalities, according to [15], are becoming geographical zones without any population and stop being towns. They represent $25 \%$ of the department population and $2 \%$ of the country. Its proximity to Bogotá, the capital of Colombia, makes them targets for departmental, local and Capital region policies, which has been promoted since 2004 and has projections until 2014.

In line with this information, there is a plan to determine the structure of the Supply Chain Network, identifying committed suppliers with a negotiation proposal without intermediaries. To improve the process and determine suitable actors that want to integrate and strengthen the power of the agreements with the association in regard to the supply of raw materials, input, Agro input, machinery, equipment and tools, with advantageous conditions like competitive prices and quality. 
During the development of the research were identified posible actors that may become part of the Supply Chain network; that is how certain entities like FINAGRO and SENA were contacted; the first one would improve the financing variable of the proposal for the cocoa farmers, and SENA would contribute technical context for the crop.

FINAGRO, under its agricultural strengthening program, that involves productive projects in any region of the country, has a line dedicated to cocoa farming thanks to state policies, for this is a world type sector, established in the Productive Transformation Program (PTP), for its potential and production growth. The proposal consists in defining the "ASCABATE" association as the leader company in the context of Supply Chains Management (SCM) to the agricultural strengthening program, -this being a requisite to enter the program, and also FINAGRO would be the spokesperson with the clients in Colombia in regard to the industrialization node, meaning, companies like Nacional de Chocolates and Casa Luker, which are part of the program, will make the most of the boosting to be given to the cocoa sector in the Cundinamarca department with the royalties, as expressed by [16].

The research team; when establishing contact with these companies, have shared the minimum requirements to buy cocoa. A special and fundamental condition for the clients is the handling and treatment of cocoa after the harvest of the crop, due to the conditions of aroma and humidity, which are the main features of each cocoa bean, as well as the procedures of planting, harvesting and post harvesting required by the buyers. The above, in order to determine the proposed production parameters and requisites of quality, Price and production, established by the clients, to be reflected to the farmers in the interest of upgrading the productive process and fulfilling the buyers' requisites.

\section{RESUlts}

Integration with the Producers in regard to the integration with the producers of the region, the ASCABATE Association (Cocoa Farmers Association of Low Tequendama), with approximately 57 associates; of which 7 , meaning $12,28 \%$ are actively producing cocoa in their lands, during the interview it was determined that the 272 cocoa hectares set in the region, 18 hectares correspond to 7 farms study targets, meaning, only $6.67 \%$ because of their condition of dynamic activity; the others have not shown interest in the association, but have the membership with other fruit crops, and in a minor scale, cocoa.
The interest of these farmers in bolstering an integration is demonstrated in how they describe common shopping among them, but not in an organized manner, oriented to a network. The goal is to make the study object farmers aware, to actively participate and make collective negotiations with the clients (Casa Luker and Nacional de Chocolates) as well as with the suppliers of agro input, equipment, tools and transportation services or technical advising. Below are detailed some of the benefits to be obtained with clients and suppliers under the integration concept.

\section{A. Integration with Clients}

When generating a continuous production volume that answers to the clients' needs, such as quality, variety and volume, they will offer a better price per cocoa kilogram; it is pertinent to approach customers like Casa Luker, for their prices are standardized in the market, and are paid thus because of cocoa variety and quality; another benefit when ensuring production volume to Casa Luker, is that on the negotiation agreement it is established the delivery of cocoa within the municipality, without having to pay transport to the warehouses in Bogota, which means savings on transport costs for Viota.

\section{B. Integration with Suppliers}

In reference to the integration with suppliers, the research team approached a supplier, according to the information given by the farmers during a structured interview about the required input for the harvest and post-harvest, and a minimum estimate was deduced for the production per hectare.

When contacting the Campeón Centro Agropecuario Company; one of the input and provisions suppliers from Bogota, they were told about the intention of integrating cocoa farmers in the region of Viota to obtain better price conditions, and negotiating as ASCABATE association, a meaningful discount can be obtained, between $5 \%$ and $10 \%$ of the acquisition total value, and additionally, the transport of the products from the region to Viota can be established in the PSA; reflecting a significant savings for the farmers in regard to freight charges; another benefit of implementing the association with this supplier is that since they represent different input brands, it opens the possibility of negotiating with the fertilizer and fungicide producing labs for advice, support and technical visits of agricultural professionals to improve crop production in the Viota region. 


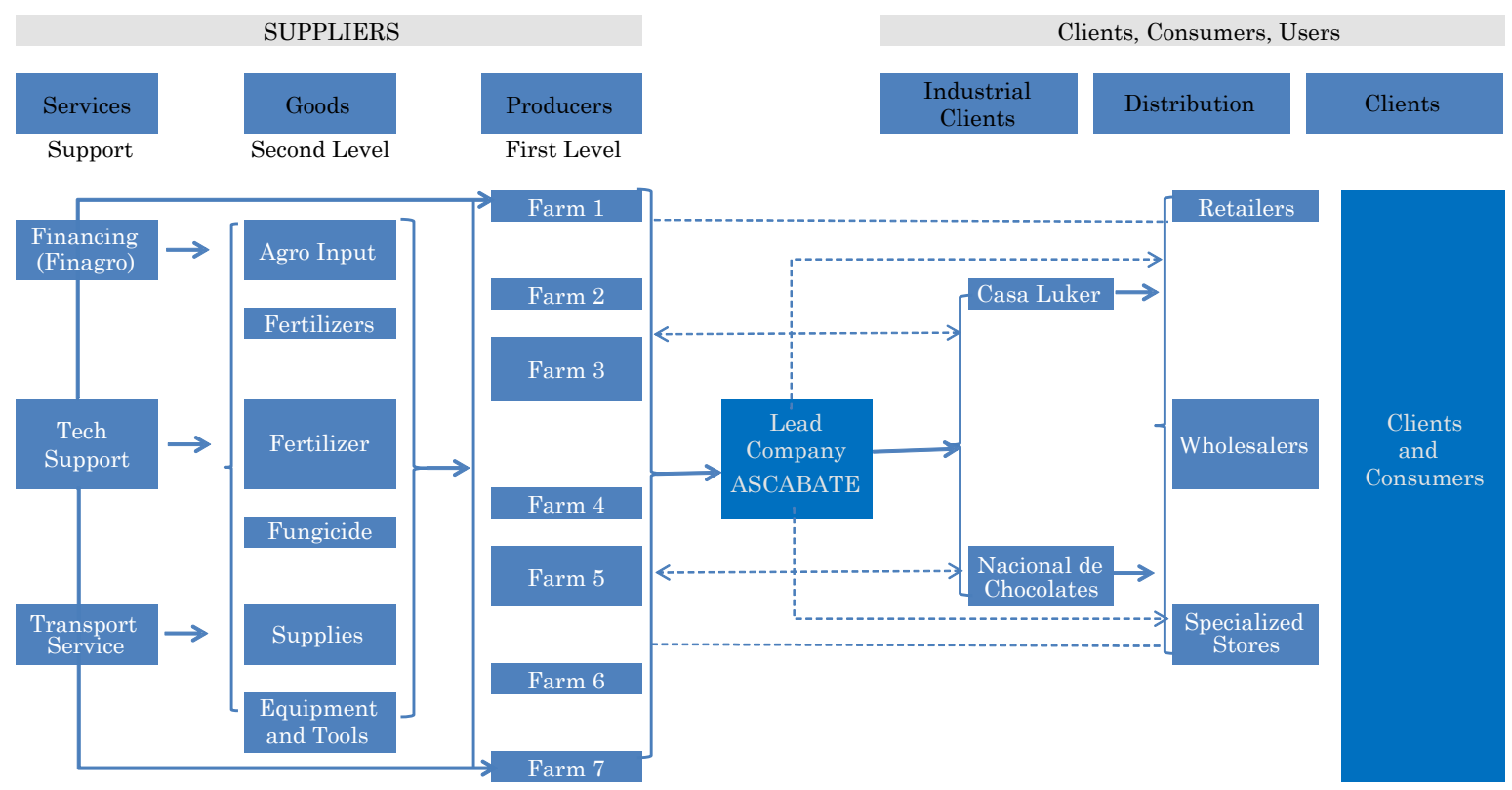

Fig. 1. Structure of Proposal of a Cocoa Supply Chain Network for the Municipality of Viota Source: Elaborated by the Research Team

\section{CONCLUSIONS}

The Supply Chain network and logistics (SCM \& Logistics) are a strategic and operational tool of great usefulness to develop the productive chains, especially the cocoa, chocolate and sweets chain, as well as constituting a continuous improvement guide for balancing the Supply Chain Management (SCM).

We propose to design a Supply Chain Network, identifying the benefits of integration, related to the knowledge and responsibility of each actor in the cocoa productive agro chain, that contribute a series of benefits for the supply and logistics in the region of Viota, Cundinamarca.

Table 7: Economic Conditions without a Supply Chain Network

\begin{tabular}{|c|c|c|c|c|}
\hline \multicolumn{4}{|c|}{ Economic Situation w/t Supply Chain Network Structure * } \\
\hline & & & $\begin{array}{c}\text { Total Cost } \\
\text { COP/ Hectare }\end{array}$ & $\begin{array}{c}\text { Total Cost COP / } \\
18 \text { Hectare }\end{array}$ \\
\hline & & TOTAL & $\$ 18.040 .628,00$ & $\$ 324.731 .304,00$ \\
\hline
\end{tabular}

Source: Research Team

Table 8: Economic Conditions with a Supply Chain Network

\begin{tabular}{|c|c|c|c|c|}
\hline \multicolumn{4}{|c|}{ Economic Situation with Supply Chain Network Structure } \\
\hline & & & $\begin{array}{c}\text { Total Cost } \\
\text { COP/ Hectare }\end{array}$ & $\begin{array}{c}\text { Total Cost COP } / \\
18 \text { Hectare }\end{array}$ \\
\hline & & TOTAL & $\$ 16.183 .065,00$ & $\$ 291.295 .170,00$ \\
\hline
\end{tabular}

Source: Research Team
Through an economic analysis we conclude that there is a significant difference of $10.3 \%$ in the performance of the farmers that integrate in a context of Supply Chain Management (SCM), establishing as a Leader Company the Cocoa Farmers Association of Low Tequendama (ASCABATE), which would result in a considerable improvement of the profitability of the business for the farmers that have the vision awareness of projection for the Cocoa Agro Chain in Viota, Cundinamarca.

In regard to producers, there is in the region the ASCABATE association (Cocoa Farmers Association of Low Tequendama), integrated by approximately 57 associates, of which 7 are linked in an active way, meaning, $12,28 \%$.

The municipality has an available area of 272 hectares to plant cocoa, however, of the 7 farms identified as leaders, there are only 18 hectares cultivated with cocoa; meaning only $6.61 \%$, we can then conclude that there is a great potential of land to cover the initial requirements of the clients - Casa Luker and Nacional de Chocolates.

The sector of chocolate, sweets and its raw materials participated with a working table in the Agreement for Prosperity dedicated to the Productive transformation Program, executed in the city of Medellin during September 23 and 24, 2011. As a result of this working table, which had the attendance of entities from the national government, company owners and associated unions, stands out as one of the agreements with greater relevance for the competitiveness of sector, the promotion and development of the National Cocoa Farmers Development 
Plan 2011 - 2021, led by the Cocoa National Council articulated with the chain and program of Productive Transformation.

The purpose of the Plan is to increase cocoa production and commercialization capacity in the country, and improve the quality of life of the families dedicated to this.

Together with the provided benefits in the environmental area, cocoa is a traditional crop of famer's economy that requires a great amount of workforce, of which is estimated that 25.000 families live from [17]. Besides, this crop is generally located in zones with social conflicts and illicit crops. In this sense, cocoa has been one of the favored products with the alternative social development programs of the former "Plan Colombia", given that cocoa constitutes a productive agroforestry project, and it is a legal source of employment and earnings, as expressed by [18].

There is an integration intention of big clients like Nacional de Chocolates and Casa Luker, being projected as a high possibility of commercial agreement by ensuring that the production volumes respond to the needs of the clients, such as quality, variety and capacity, reflected in a balanced price per kilogram of cocoa, in regard to the market.

\section{RECOMMENDATIONS}

The research team recommends to develop an awareness plan related to the subject of Supply Chain Networks; in order to integrate a greater number of farms (at least 50\%) around the ASCABATE association, to participate actively in the structuring of the negotiation agreements, for the clients as well as for the input and services providers, and increase benefits like:

- Improve sales volume.

- Reduction of freight costs.

- Negotiate a better purchase price of input and services.

- Negotiate a better sale price of the product.

- Technical support for the crop.

Once this research work is concluded, the team recommends to implement the value network, according to the proposed model, for the social economic benefit of cocoa farming region of the Viota municipality.

It is convenient to perform sociological and technical studies to characterize the region and its inhabitants in order to specialize in a sectorial and intelligent manner the agro industry to make the zone into a highly developed and competitive zone.

The research team suggest the generation of approaching and negotiation spaces with the big cocoa purchasing companies and farmers of the product in Viota, this would improve the support and development of products with the required quality, the modernization of farms, and improvement of the families' earnings and progress of the region.

\section{REFERENCES}

[1] Swisscontact, "Desarrollo de la cadena del valor. Cacao," Zurich, 2012

[2] Grupo de Investigación Universidad Piloto, "Modelo Productivo y Asociativo Cadena de Abastecimiento del Cacao en las provincias de Sumapaz y Tequendama (Cundinamarca) epicentro Viotá." Universidad Piloto de Colombia, Bogotá, 2013.

[3] L. Moreno Malagón, "Propuestas de Competitividad y Productividad en Taller de Jóvenes Rurales," 2012. [Online]. Available: http://senagirardot.blogspot.com. co/2012/10/propuestas-de-competitividad-y.html. [Accessed: 08-Jan-2015].

[4] H. Mora, "Cundinamarca a la vanguardia en cadena productiva del cacao," PeriodismoPublico.com, Cundinamarca, 29-Nov-2010.

[5] O. Castellanos, L. Torres, S. Fonseca, V. Montañez, And A. Sánchez, "Agenda prospectiva de investigación y desarrollo tecnológico para la cadena productiva de cacao-chocolate en Colombia,” Bogotá, 2007.

[6] C. Rodríguez, "Otorgamiento del subsidio integral para la compra de tierras para la población en situación de desplazamiento," Nariño, 2009.

[7] Ministerio de Agricultura y Desarrollo Rural and Observatorio Agrocadenas Colombia, "La Cadena de Cacao en Colombia," Bogotá, 2004.

[8] Ministerio de Comercio Industria y Turismo, La Política Industrial durante el Gobierno del Presidente Juan Manuel Santos. Bogotá, 2013

[9] J. Santos, "Informe al Congreso." Secretaría de Prensa, Bogotá, 2011.

[10] Alcaldía de Viotá, "Viotá - Cundinamarca," Sitio oficial de Viotá en Cundinamarca, Colombia, 2016. [Online]. Available: http://www.viota-cundinamarca.gov.co/informacion_general.shtml. [Accessed: 08-Jan-2015].

[11] A. I. Barrera Rodríguez, J. Baca Del Moral, H. V. Santoyo Cortés, and J. Reyes Altamirano Cárdenas, "Propuesta Metodológica para Analizar la Competitividad de Redes de Valor Agroindustriales," Rev. Mex. Agronegocios, vol. 17, no. 32, pp. 231-244, 2013.

[12] ASCABATE, "Propuestas Agricultores del bajo Tequendama - ASCABATE," 2013. [Online]. Available: http://www.urnadecristal.gov.co/propuesta/propuestas-agricultores-bajo-tequendama-ascabate.

[13] J. Hurtado Hernández, "Viotá Territorio de Paz," Municipio de Viotá., 2013. [Online]. Available: http:// paolahurtado211.blogspot.com.co/2013/02/resena-historica-fecha-de-fundacion-27.html. [Accessed: 04-Jan2015].

[14] L. Galindo Cáceres, Técnicas de investigación en sociedad, cultura y comunicación. México: Pearson Educación, 1998.

[15] DANE, "Censo Metodológico del Cacao," 2014. [Online]. Available: https://www.dane.gov.co/files/investigaciones/agropecuario/ena/doc_met_cacao.pdf. [Accessed: 23-Nov-2014]

[16] Departamento Nacional de Planeación, "En Cundinamarca se ejecutó con éxito el primer proyecto de cacao con regalías," 2014. [Online]. Available: https://www. sgr.gov.co/Prensa/ComunicadosdePrensa/tabid/82/ EntryId/569/En-Cundinamarca-se-ejecuto-con-exitoel-primer-proyecto-de-cacao-con-regalias.aspx. [Accessed: 08-Feb-2015].

[17] Departamento de Cundinamarca, "Plan de Desarrollo Departamento de Cundinamarca 2012 - 2016," 2012. [Online]. Available: http://www1.cundinamarca.gov. co/gobernacion/Portals/0/Anexos/Cundinamarca-Calidad-de-Vida-CTP-solotexto.pdf.

[18] Ministerio de Agricultura y Desarrollo Rural, "La cadena del cacao en Colombia. Una mirada global de su estructura y dinámica 1991 - 2005," Bogotá, 2005. 